\title{
観光旅行者の観光資源に対する 空間的魅力度
}

\author{
神 頭 広 好*, 西, 岡 久 雄**
}

\section{1.はじめに}

観光に適用できるサービス産業の立地論は殆どなくはっきりした効能もない，と見られている ようで, S.J. スミス[20]は，「この方面におけるこれまでの試みは，非現実的な仮定が多すぎ，経 験的データが不足し, かつ恐らく観光景観 [地域] の発展に要する諸要因の理解が余りにも素朴 であるということのため，限定された価值を持つに留まってきた。」すするこれに対し C.A.ガ ン [8] は，自著中のサービスに関する章で，旅客への飲食提供業務はたいていの場合，地元市場 にも提供するものであるから，「店舗やレストランの立地についての或る一般的な諸原理は，観光 にも妥当する。」をす。しかしこれらの議論は，個々の観光事業所または観光地の立地を主とし て考えているようである。観光学説史の権威である塩田正志教授 $[19] に よ る と ， 1960$ 年代に，ド イツのペッシュル [18］が社会経済学的研究と言うべき『観光と観光政策』で，都会の吸引力と 田舎への逃避の遠心力の対抗と交替や, 限界生産力法則の適用を論じ, 同じくドイツのトット [24] が「旅行目的地の空間秩序について」でポテンシャル・モデル等を用い, またフランスのドゥフェー ル [6] は『観光立地論』を著し，フランス各地のデータに基づく実証的研究から，いくつかの原 理と系を提示している。

ドゥフェールは自著において，観光立地では，(a) 輸送費以外の異なった要素（テレックス・電 話料）が重要である，(b) 自然決定論に従う，(c) 交通手段が多様化し，鉄道輸送だけでは理解で きない，(d) 距離は観光客に心理的隇価 (depreciation psychologique) を与える，(e) 商品ではな く, 人が移動する，(f) 完全競争からはほど遠く, 独占市場に近い, といった理由で, チェーネン やフーヴァーの立地論の単純な適用は意味がない，とする。

しかしながら，(a)については，輸送費以外の異なった要素もまた重要というべきであろう。(b) は非常に顕著な自然的な観光資源の所在についてのみいえる ことで，その場合でも，フーヴァー

$*$ 愛知大学経営学部

** 青山学院大学経済学部 (名誉教授) ; 駿河台大学文化情報学部 本研究は，第 30 回日本地域学会国内大会（於，青山学院大学）において報告したものに加筆修正を加えた ものである。討論者である石川利治氏 (中央大学) ならびに板谷雄二氏（朝日大学）加有益なコメントを 頂き，さらに，レディング大学の Evans 教授ならびに Meen 博士からもご示唆頂いたことに対して謝意を 表する。

1)もし「自然決定論」を言うのであれば，「歴史決定論」とも言えるはずで，西岡 [17］が紹介したテイスデ ル [23] の言うリカード型（唯一またはそれに近いもの）の観光資源（たとえば，サンピエトロ）はそれに 属することになろう。 
[9] や西岡久雄 $[11,12,13]$ のいう抽出産業（extractive industry一ただし，フーヴァーは農業 等の土地利用産業を含み，西岡はそれを別個のタイプとする）としての立地及びそれに伴う市場 地域や集積度または利用強度などの問題がある。(c) に対しては, 交通手段の進歩あるいは多様化 は立地論を無意味にするものでは少しもないといわねばならない。(d) は，広義の集積論に属する といえる中心地論や引力・ポテンシャル系モデルの適用の有効性を示唆するものであり（事実彼 の言う原理等は，引力・ポテンシャル系モデルの応用成果のように思える）が，同時に，集積の 利益または効果, あるいはまた心理的距離に及ぼすイメージの影響等を, 積極的に考慮すべきこ とをも示唆しているといえる。(e) は，チューネンの立地論から着想されたアロンソ [1] 型の立地 論の応用可能性を考慮すべきことを示唆する。(f) は, 立地論の一分野である空間競争論, あるい はまた製品差別化したがって独占的競争等を想定すべきことを，また，製品またはファッション のサイクルにも留意すべきことを意味しよう。

経済学の立場からの観光研究については，西岡［16] がサーベイを行なったが，その中で立地 論及びその拡延的発展といえる空間経済論の観点から注目できるのは，上記の海外の諸家や除野 信道 [25]，そしてとりわけ，立地論家でもあるフォン・ベーヴェンター［5］の『観光経済学』で あろう。ベーヴェンターは多分, ナチスを批判したためハイデルベルク大学を去って戦時中山荘 にこもっていたアルフレート・ヴェーバーが戦後同大学に復帰してからの弟子であったようで, 戦 後ドイツの代表的な立地論家である。西岡は彼が独特の六角形網市場組織とヴェーバー的な指 向・集積概念とを結び付けて経済の空間構造を論じている論文 [3] に感銘，紹介したことがある。 彼の上記著書 [5] の目的は, 経済学的研究の一対象としての観光 (Tourismus), 特に休暇旅行 を分析するための組織的・体系的な原論を提供することにあるといえるが，チューネンを含む経 済立地論あるいは空間経済理論の考え方が生かされている点に，大きな特色がある。したがって， 当然のことながら，休暇旅行の「距離」が重要な変数とされている。また，われわれはチューネ ン的思考の重要な特徵の一つを, 均質平野を前提とする第一次的接近と, その前提を解除または 変更した場合の第二次接近とから成り立っていることにあるとしてきた(西岡[14])が，ベーヴェ ンターも均質的休暇平野の場合の理論（Theorie der homogenen Urlaubsflache）から差異的 (differenzierte) あるいは非均質的休㗇平野の場合のそれへ，と議論を進めているのである。住宅 等に関する議論も, チューネン的思考の特色に立脚するアロンソ〔1]の理論が出現してはじめて 大きく進歩したことが, 想起されよう2)。なお, 神頭 [10] は, 観光旅行者行動に照準をあて上記 のアロンソ [1] の付け值地代の概念を観光地に応用して「ホテルサービスに対する均衡付け值関 数」を導出している。また，そこでは観光の外部経済効果を考慮した観光資源市場サイズに関す る分析も行なっている。

上記の研究成果の中でも特に西岡及びベーヴェンターの立地論的見解を踏まえつつ，アロンソ の宅地の付け値関数にもとづいて，観光旅行者が観光地域内のどの立地点の観光ホテルを選択す

\footnotetext{
2) ちなみに, ベーヴェンター [4] によれば, アロンソの理論は, チューネンーダン型理論の一発展である。
} 
るかによって，言い換えればホテル付け值（宿泊代）関数を導くことから，観光旅行者の観光資 源に対する空間的魅力度（ここでは，観光資源中心部からの距離に対する効用弾力性）が計られ るという前提に立ち，まず観光旅行者の効用関数を特定化させることによって，観光予算制約の 下での効用最大化条件式から観光旅行者の観光資源に対する空間的魅力度を計測するための関数 を導出する。ついで，同関数を用いて観光予算の配分別及び観光地域のサイズ別に「観光資源中 心部からの距離」に関して「観光資源に対する空間的魅力度」がぞの程度変化しうるかについて シミュレーション分析を試みる。

\section{2. 理論モデルとシミュレーション}

\section{1 理論モデル}

ここでは，均質平野の中心に，美しい景観を有する湖または城廓が位置しており，そこから風 光明媚な森林及び伝統的建築物が広がっている観光地域を念頭において，次の諸仮定を設定しよ う。

（1）観光資源は，均質平野上の円形の観光地域の中心部に位置している（図 1参照）。

（2）観光旅行者の効用は，「観光資源中心部からの距離」及び「観光合成財」3) からなる。

（3）観光旅行者の予算は，「観光ホテル宿泊代」，「観光合成財支出」及び「交通費」からなる。

（4）観光ホテルから観光資源中心部までは，徒歩で行くか観光ホテルのバスサービスがある。

(5). 観光地域における各観光ホテルの部屋に関するスペース及びサービスは,それぞれ一律で ある。

上記の仮定にもとづき,観光旅行者の効用関数を指数タイプに特定化させると次のようになる。

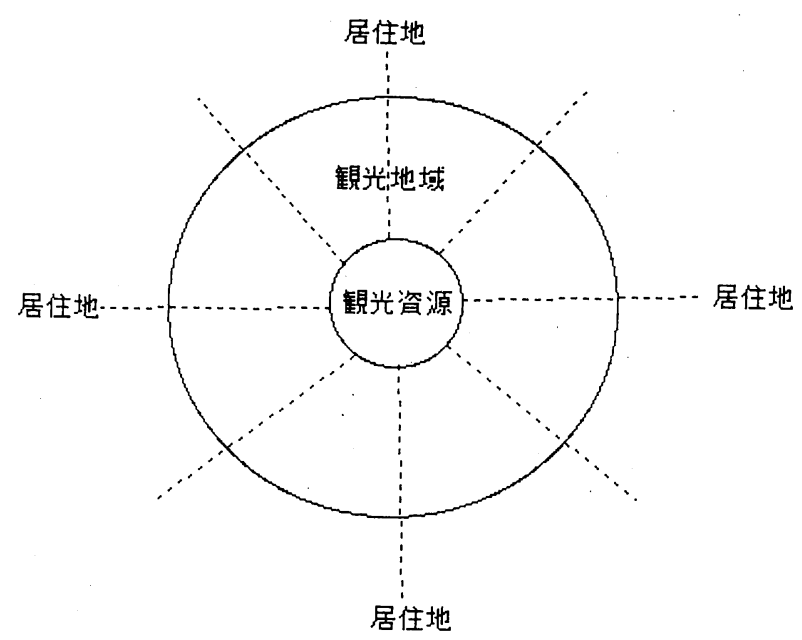

図 1 観光地域図

\footnotetext{
3)ここでの観光合成財とは，観光旅行期間中に消費されるすべての財によって構成されるバスケットを指す。
} 


$$
u=t^{-\alpha} z^{\beta}
$$

ただし, $u$ : 観光旅行者の効用, $t$ : 観光資源中心部から観光ホテルまでの距離, $z:$ 観光合成財, $\alpha$ 及び $\beta: t$ 及び $z$ に対する魅力係数 ${ }^{4)}(\alpha>0, \beta>0)$

つぎに，観光旅行者の予算は，

$$
y=p(t)+p_{z} z+k(l-t) .
$$

ただし, $y$ : 観光旅行者の予算, $p(t)$ : 観光ホテル宿泊代, $p_{z}$ : 観光合成財単位当たり価格, $k(l-t)$ : 居住地から観光ホテルまでの交通費, $l$ : 観光資源中心部から居住地までの距離

ここで，予算制約のもとで効用最大化の条件を導出するためにラグランジュ乗数法を用いて観 光旅行者の効用最大化に関する 1 階の条件を表すと，ラグランジュ乗数式

$$
L=t^{-\alpha} z^{\beta}+\lambda\left(y-p(t)-p_{z} z-k(l-t)\right)
$$

から，

$$
\begin{aligned}
& \frac{\partial L}{\partial t}=-\alpha \frac{u}{t}-\lambda\left(p^{\prime}(t)-k^{\prime}(l-t)\right)=0 . \\
& \frac{\partial L}{\partial z}=\beta \frac{u}{z}-\lambda p_{z}=0 \\
& \frac{\partial L}{\partial \lambda}=y-p(t)-p_{z} z-k(l-t)=0 .
\end{aligned}
$$

上記 (1) 式及び (2) 式から，入を消去して整理すると，

$$
-\frac{\alpha}{\beta} \frac{p_{z} z}{t}=p^{\prime}(t)-k^{\prime}(l-t)
$$

また，上記 (4) 式を（3）式で除することによって整理すると，

$$
\frac{\alpha}{\beta} \frac{1}{t}=\left(\frac{-p^{\prime}(t)+k^{\prime}(l-t)}{y-p(t)-k(l-t)}\right) \text {. }
$$

さらに，これを $t$ で積分すると，

$$
\frac{\alpha}{\beta} \int_{1}^{t_{m}} \frac{1}{t} d t=\int_{1}^{t_{m}}\left(\frac{-p^{\prime}(t)+k^{\prime}(l-t)}{y-p(t)-k(l-t)}\right) d t .
$$

したがって，

$$
\frac{\alpha}{\beta} \log t_{m}=\log \left(\frac{y-p\left(t_{m}\right)-k\left(l-t_{m}\right)}{y-p(1)-k(l-1)}\right)
$$

ただし，観光資源中心部の半径は 1 単位存在するものとして，観光資源中心部における観光ホ テル宿泊代は $p(1), t_{m}$ を観光資源中心部から観光地域境界地までの距離とすると，観光地域境界 地における観光ホテル宿泊代は $p\left(t_{m}\right)$ とそれぞれ表される。

4)一般にこれは, 研究の目的によって弾力性またはパラメーターと呼ばれているが, ここでは Beckmann[2] にしたがって, 魅力係数 (coefficient of attractiveness) と呼ぶ。 
また（5）式の観光地域境界地点における観光ホテル宿泊代 $p\left(t_{m}\right)$ をほとんどゼロに近いものと しで）整理すると,

$$
\frac{\alpha}{\beta} \log t_{m}=\log \left(\frac{y-k\left(l-t_{m}\right)}{y-p(1)-k(l-1)}\right) .
$$

さらに，ここで $n$ 次同次の効用関数を仮定すると，すなわち $-\alpha+\beta=n$ から

$$
\alpha=\frac{n \log \left(\frac{y-k\left(l-t_{m}\right)}{y-p(1)-k(l-1)}\right)}{\log t_{m}-\log \left(\frac{y-k\left(l-t_{m}\right)}{y-p(1)-k(l-1)}\right)} .
$$

以後この $\alpha$ を「観光資源に対する空間的魅力度」と呼ぶ。

\section{2 シミュレーション}

ここでは, 2.1の (7) 式から実際に観光旅行者の観光予算に関するデータ等を得ることが難しい ため，やむをえずシミュレーション分析を試みた。その分析結果及び考察については以下の (a) 〜(d)に示されている。ただし，ここでは同式を明示することと，同式の感度を調べるという点か ら，(7) 式の $n$ を 1 として計算されているが, 通常の限界効用派減の前提を考慮すると $0<\alpha<1$ 及び $0<\beta<1$ が満たされるためには $n$ が $0<n<1$ の範囲になければならず，その結果以下の各 図における $\alpha$ はより小さく見積られていることに注意する必要がある。また，恣意的ではあるが 国内旅行において平均的範囲内に入ると予想される值を各変数に応用した。さらに本モデルにお いて $k(l-t)$ を交通費用関数としているため, $k(l-t)=a(l-t)$ とすると $a$ は運賃率を示してお り，これについては，自家用車，鉄道及び観光バスの何れを利用するかによってかなりの違いが あることに注意する必要がある。

(a) 図 2 に示されている様に，他の条件 (観光資源中心部における観光ホテル宿泊代 (3 万円),
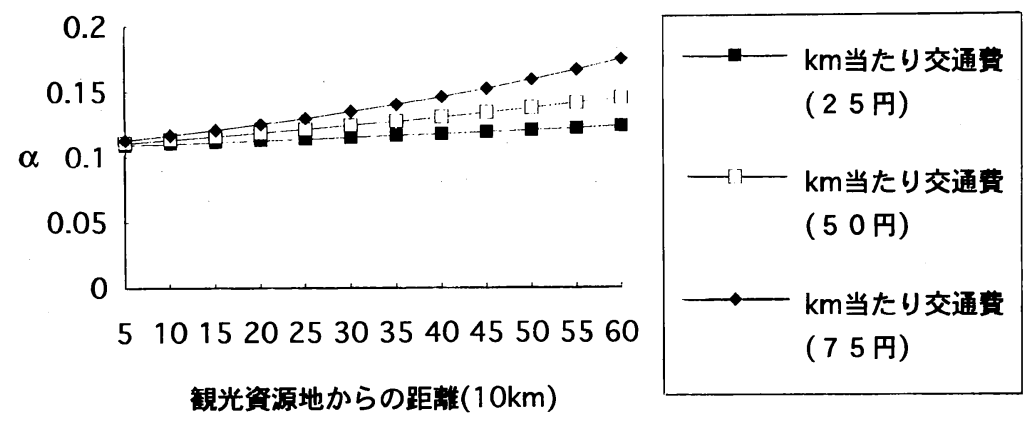

図 2 交通費別魅力度 $(\alpha)$ 及び距離

5) 言い換えれば, これは, 観光ホテルとしての立地の有意性がなくなることを示唆しており,また変数を減ら すことによって，シミュレーション分析の簡素化を計るためである。 
観光予算（15 万円）及び観光地域の半径 ${ }^{6)}(10 \mathrm{~km})$ を一定とすれば，遠方で，交通サービス水準 の低い地域に居住している観光旅行者ほど観光資源に対する空間的魅力度 $(\alpha)$ が高く，またそれ は観光資源中心部から距離に対して逓増する。言い換えれば，このことは，観光資源中心部から 遠くに住んでいる観光旅行者ほど, 観光資源に対する魅力に関してより高く評価する傾向を示し ていると言えよう。

(b) 図 3 に示されている様に, 他の条件 (観光資源中心部における観光ホテル宿泊代 (3 万円), $\mathrm{km}$ 当たり交通費 $(50$ 円）及び観光地域の半径 $(10 \mathrm{~km}))$ を一定とすれば，相対的に観光予算の 低い観光旅行者ほど観光資源に対する空間的魅力度 $(\alpha)$ が高く, 上記 (a) 同様にそれは観光資源 中心部からの距離に対して逓増する。これは, 各居住地点において観光予算が相対的に低い観光 旅行者ほど，また観光地域からより遠くに立地している観光旅行者ほど，観光資源に対する空間 的魅力度 $(\alpha)$ が相対的に高いことを示唆している。逆に, 高所得階層ほど観光予算を高く組める という前提の下では, 観光地域からより近い所に立地している高所得階層ほどその観光資源に対 する空間的魅力に関しての評価が低いことを示している。さらに, 3 つのケースではあるが観光予 算が高まれば高まるほど, 各居住地点における観光旅行者の観光資源に対する空間的魅力度 $(\alpha)$

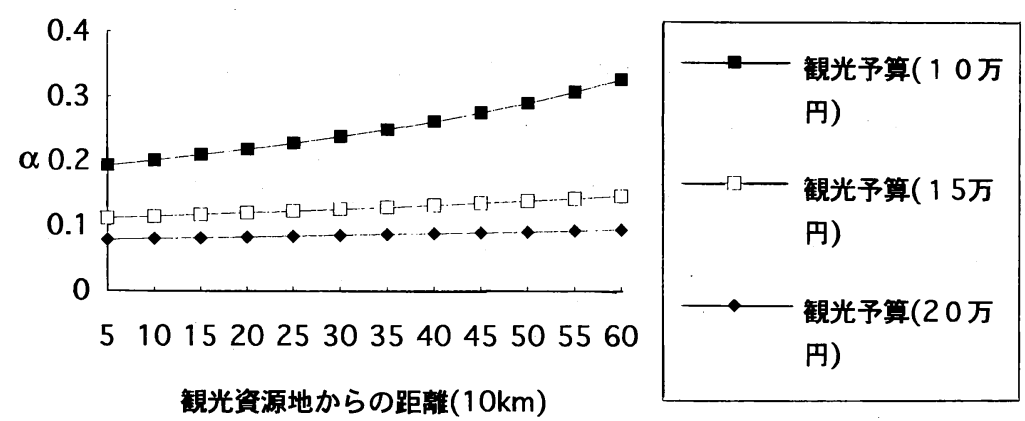

図 3 観光予算別魅力度 $(\alpha)$ 及び距離

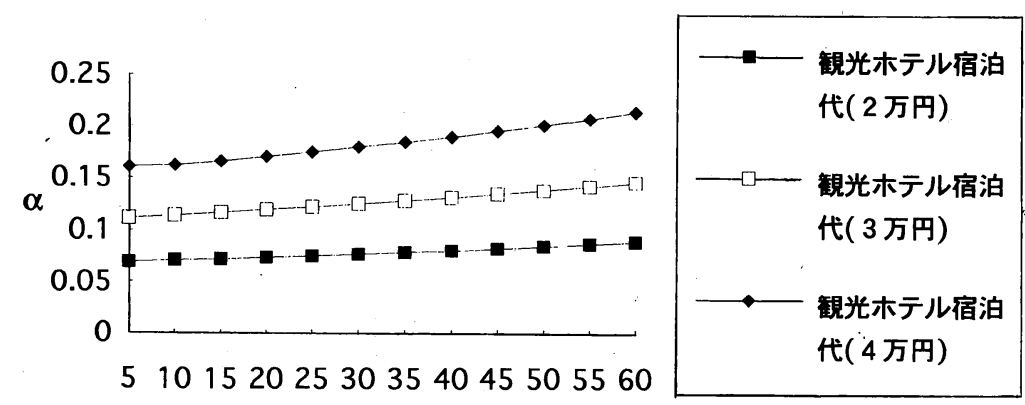

観光資源地からの距離 $(10 \mathrm{~km})$

図 4 観光資源中心部におけるホテル宿泊代別魅力度 $(\alpha)$ 及び距離

6) 厳密に言えば,これは, 観光資源中心部から観光地域界地点までの距離を示す (以下同様)。 

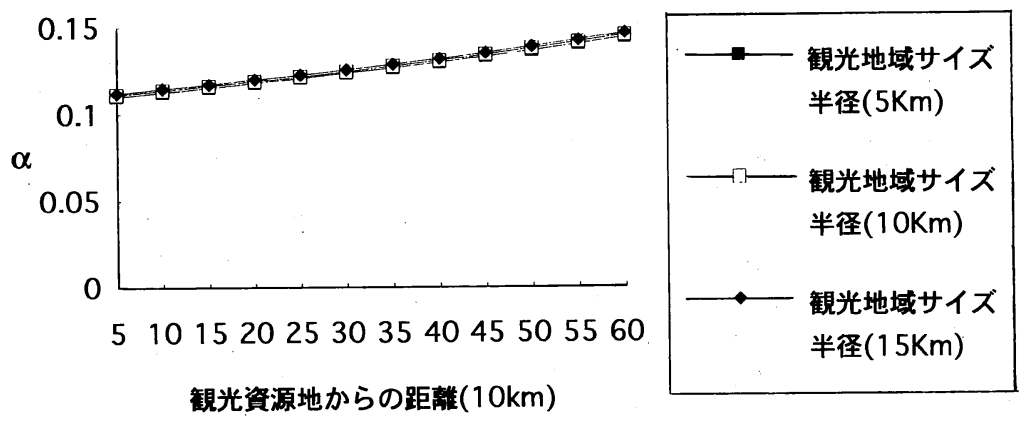

図 5 観光地域サイズ別魅力度 $(\alpha)$ 及び距離

の減少割合がより小さくなることを示している。

(c) 図 4 に示されている様に, 他の条件 (1 km 当たり交通費 (50 円), 観光予算 (15 万円) 及 び観光地域の半径 $(10 \mathrm{~km}))$ を一定とすれば, 観光資源中心部におけるホテルの宿泊代が高いケー ス（または宿泊日数が多いケース）䚾ど観光旅行者の観光資源に対する空間的魅力度 $(\alpha)$ が高く, それは観光資源中心部からの距離とともに逓増する。これは，観光資源中心部からより遠くに居 住している観光旅行者ほど，観光資源に対する魅力に関してより高い評価をしており，その結果 観光資源中心部により近い所に立地しているホテルに対して高い付け值（宿泊代）を提示するか, 宿泊日数を増やすことを示唆している77。

(d) 図 5 に示されている様に，他の条件 (観光資源中心部における観光ホテル宿泊代 (3 万円), $1 \mathrm{~km}$ 当たり交通費（50 円）及び観光予算（15 万円）を一定とすれば，観光地域のサイズの大小 にかかわらず，観光資源に対する空間的魅力度 $(\alpha)$ が各居住地点において，ほとんど変わりない ことを示している。すなおち，このことは同一の観光資源に対する空間的観光地域開発は，観光 旅行者の効用にそれほど大きなインパクトを与えないことを示唆している。

3. 結 び

本研究では，まず，観光学に関する主たるサーベイを行ない，それに対して検討を加え，フー ヴァー [9] 及び西岡 $[11,12,14]$ の立地論的見解を通じて立地論の観光経済学への応用可能性 を示唆した。さらに，ベーヴェンター［5］の『観光経済学』に着目して，観光立地論がチューネ ン［22］理論及びそれに基礎をなすとされるアロンソ：[1] 理論と関連性があることを指摘した。 ついで，アロンソの付け值地代理論にもとづいて，観光旅行者の予算制約のもとでの効用最大化 に関する空間的条件式から観光旅行者の観光資源に対する空間的魅力度を計測するための関数を 導出し，最後に同関数を用いてシミュレーション分析を試みた。その結果，観光資源中心部から より遠くに住んでいる観光旅行者ほど，観光資源に対する空間的魅力に関してより高く評価する こと。また，それによって観光資源中心部に立地している観光ホテルに対して高い付け值（宿泊

7)このことは，観光ホテル宿泊代が観光資源に対する hedonic price であるという考え方にもとづいている。 
代）を提示するか，宿泊日数を増やす傾向にあることなどが考察された。しかし，そこでは効用 関数型で決まってしまう当然と言えるような結果しか得られなかったが，観光旅行者の観光資源 に対する空間的魅力度について, 観光予算及び観光地域サイズの相違による変化を空間的に明示 できたことは本モデルの理解を容易にしたものと考える。さらに, 本モデルを通じてチューネン・ モデルにおける空間的接近法及び付け值地代の概念が，ホテル立地または観光旅行者行動モデル に対して応用可能性を有していることなどが示唆された。したがって，今後の課題としては，本 モデルに適合するような観光資源単一中心夕イプの観光地域を見い出すために，第 1 章における 文献等を整理することによって観光資源の自らの特性 ${ }^{8)}$ のならず，観光地域及び居住地域を含 む地理的条件及び交通サービス水準，また可能であればアンケート調査デー夕等を利用して，観 光旅行者の予算水準及び年齢構成等のデー夕を踏まえた上で, 観光旅行者行動に関するモデル構 築を行ない，観光旅行者（または家計）の効用関数を特定化させることによって観光ホテルの付 け值 (宿泊代) 関数を導出することが必要である。それによって観光地的構造特性が生かされた, より現実的な観光旅行者の観光資源に対する魅力度分析がなされよう。さらに，そこでは観光ホ テルをリゾートマンション及び別荘に置き換えて分析することも可能である。他方，ここでは観 光合成財に対する魅力度については触れなかったが, 観光地域の企業立地モデルを考える際には, 同魅力度分析が必要となろう。最後に観光資源は一般に公共財的性格を有していることなどから， 公共経済学及び厚生経済学の各観点からも観光立地論に対してアプローチする必要がある。

\section{参考文献}

[1] Alonso, W., Location and Land Use, Harvard University Press, 1964（折下 功訳『立地と土地利 用』朝倉書店, 1966)。

[2] Beckmann, M.J., "Spatial equilibrium in the housing market," Journal of Urban Economics, 1, 1974, pp. 99-108.

[ 3 ] Böventer, E. von, "Die Struktur der Landschaft," in Optimales Wachstum und Optimale Standortverteilung, by R. Henn, G. Bombach und E. von Böventer, Berlin: Duncker \& Humblot, 1962.

[4] Böventer, E. von, "Toward a United Theory of Spatial Economic Structure," Papers, Vol. 10, Regional Science Association, 1963.

[5] Böventer, E. von, Ökonomische Theorie des Tourismus, unter Mitarbeit von Kai Vahrenkamp, Frankfurt/Mein : Campus Verlag, 1989.

[6] Defert, P., La localisation touristique, 1966.

[ 7 ] Dunn, E.S., The Location of Agricultural Production; University of Florida Press, Gainesville, 1954 (阪本平一郎，原納一雅訳『農業生産立地論』地球出版，東京，1960).

[ 8 ] Gunn, C.A., Tourism Planning, Taylor \& Francis, 2nd ed., 1988, pp. 140-141.

[9] Hoover, E.M., Location Theory and the Shoe and Leather Industries, Harvard University Press, 1937 (西岡久雄訳『経済立地論』大明堂, 1968)。

［10］神頭広好『観光資源サービスに対する外部経済効果」日本観光学会『研究報告』第 15 号，1985.

［11］西岡久雄「経済立地の分析」(国松久弥他共著『経済地理学』明玄書房，1965，所収）。

[12］西岡久雄『経済立地の話』日経文庫，1968．

8)これについては, 鈴木 $[21]$ および西岡 $[15,17]$ によって説明されている。 
［13］西岡久雄『経済地理分析』大明堂，1976，増補版，1986.

[14] 西岡久雄『立地論』大明堂, 1988, 増補版, 1993.

［15］西岡久雄『観光地域の評価と観光施設の立地決定」『青山経済論集』第 44 巻, 第 4 号, 1993 年 3 月, pp. 107-131.

［16］西岡久雄「観光経済学の構想について」『青山経済論集』第 45 巻，第 1 号，1993 年 6 月，pp. 63-89.

[17］西岡久雄「観光，環境，および開発」『青山経済論集』第 45 巻，第 2 号，1993 年 10 月，pp. 53-82.

[18] Pöschl, A.E., Fremdenverkehr und Fredenverkehrspolitik, 1962.

[19] 塩田正志『観光学研究・I』学術選書, 1975.

[20] Smith, S.J., "Restaurants and Dinning Out-Geography of a Tourism Business," Annals of Tourism Research, 10, 1983, pp. 515-549, 特に p. 518.

[21］鈴木忠義編『現代観光論「新版」』有斐閣, 1984.

[22] Thünen, J.H. von, Derisolierte Staat in Beziehung auf Landwirtshft und Nationalokononie, Hamberg, 1826；第 2 部，Rostock, 1850 及び 1863, 等（近藤康男訳『独立国』農村漁村文化協会，1974）。

[23] Tisdell, Clement A., Economics of Environmental Conservation, Elsvier, 1991.

[24] Todt, H., Über die räumliche Ordnung von Reisezielen, Frankfut M., 1965.

[25]. 除野信道『観光社会経済学』古今書院，1975, 改訂版 1985.

\title{
The Spatial Attractive Degree to the Tourism Resource of Tourist
}

\author{
Hiroyoshi Kozu* and Hisao NisHIKA**
}

We first attempt to survey articles of tourismology and considering some views of Hoover and Nishioka, point out that location theory can be applied to tourism. Next, by paying attention to Ökonomische Theorie des Tourismus by von Böventer (1989), we indicate that the theory of tourism location has a close relationship to each theory of Thünen (1826) and Alonso (1964). Then it is supposed that the degree of spatial attraction to the tourism resource (i.e., the elasticity of the tourist's utility with respect to the distance from the central place of the tourism resource) is measured by which tourism hotel the tourist chooses within the tourism region from the standpoint of the bid rent theory based on Alonso (1964). Moreover by specifying the utility function of the tourist, we derive a function to measure the degree of spatial attraction. Finally, we attempt a simulation analysis concerning items of the tourist's budget and the size of the tourism region by making use of this function. The tourist living in a further region from the tourism resource has stronger spatial attractiveness to the tourism resource and if the tourism region is expanded by bigger development, the degree of spatial attraction to the tourism resource falls in each residential location.

\footnotetext{
* Aichi University, Faculty of Business Administration

** Aoyama Gakuin University, Department of Economies (Projessor Emeritus:) ; Surugadai University, Faculty of Cultural Information Resources, April, 1994
} 